\title{
Hematological profile of normal pregnant women in Lagos, Nigeria
}

This article was published in the following Dove Press journal:

International Journal of Women's Health

2 May 2013

Number of times this article has been viewed

\section{Akinsegun A Akinbami' \\ Sarah O Ajibola ${ }^{2}$ \\ Kabiru A Rabiu ${ }^{3}$ \\ Adeniyi A Adewunmi ${ }^{3}$ \\ Adedoyin O Dosunmu' \\ Adewumi Adediran ${ }^{4}$ \\ Vincent $O$ Osunkalu ${ }^{4}$ \\ Bodunrin I Osikomaiya ${ }^{5}$ \\ Kamal A Ismail ${ }^{5}$ \\ 'Department of Haematology and Blood Transfusion, Lagos State University, College of Medicine, 2Department of Haematology and Blood, Lagos University Teaching Hospital, ${ }^{3}$ Department of Obstetrics and Gynaecology, Lagos State University, College of Medicine, ${ }^{4}$ Department of Haematology and Blood, Faculty of Clinical Sciences, College of Medicine, University of Lagos, ${ }^{5}$ Department of Haematology and Blood Transfusion, Lagos State University Teaching Hospital, Lagos, Nigeria}

Correspondence: Akinsegun A Akinbami Department of Haematology and Blood Transfusion, Lagos State University, College of Medicine, Ikeja, Lagos, Nigeria Tel +234 I 8023064925

Email ajoke_clinic@yahoo.co.uk
Background: Hematological profile is considered one of the factors affecting pregnancy and its outcome. Anemia is the most common hematological problem in pregnancy, followed by thrombocytopenia. Leukocytosis is almost always associated with pregnancy. The study reported here was designed to evaluate the overall mean values of seven major hematological parameters and their mean values at different trimesters of pregnancy.

Subjects and methods: This examination was a cross-sectional study of 274 pregnant women who registered to attend the Lagos University Teaching Hospital or Lagos State University Teaching Hospital antenatal clinics between their first and third trimester. Blood (4.5 mL) was collected from each participant into a tube containing the anticoagulant ethylenediaminetetraacetic acid (EDTA). A full blood count was performed on each sample and the results were analyzed.

Results: Overall, the values obtained were (mean \pm standard deviation [SD]): hematocrit level, $30.16 \% \pm 5.55 \%$; hemoglobin concentration, $10.94 \pm 1.86 \mathrm{~g} / \mathrm{dL}$; white blood cells, $7.81 \pm 2.34 \times 10^{9}$; platelets, $228.29 \pm 65.6 \times 10^{9}$; cell volume $78.30 \pm 5.70 \mathrm{fL}$, corpuscular hemoglobin, $28.57 \pm 2.48 \mathrm{pg}$; and corpuscular hemoglobin concentration, $36.45 \pm 1.10 \mathrm{~g} / \mathrm{dL}$. When grouped by trimester, the mean \pm SD value of packed cell volume at first trimester was $32.07 \% \pm 6.80 \%$; of second trimester, $29.76 \% \pm 5.21 \%$; and of third, $33.04 \% \pm 3.88 \%$. The mean \pm SD hemoglobin concentration values were $11.59 \pm 2.35 \mathrm{~g} / \mathrm{dL}, 10.81 \pm 1.72 \mathrm{~g} / \mathrm{dL}$, and $10.38 \pm 1.27 \mathrm{~g} / \mathrm{dL}$ for women in their first, second, and third trimester, respectively. Mean $\pm \mathrm{SD}$ white blood cell concentration for first, second, and third trimesters were $7.31 \pm 2.38 \times 10^{9}$, $7.88 \pm 2.33 \times 10^{9}$, and $8.37 \pm 2.15 \times 10^{9}$, respectively, while the mean \pm SD platelet values for first, second, and third trimesters were $231.50 \pm 79.10 \times 10^{9}, 227.57 \pm 63 \times 10^{9}$, and $200.82 \pm 94.42 \times 10^{9}$, respectively. A statistically significant relationship was found to exist between packed cell volume and white blood cell count with increase in gestational age $(P=0.010$ and 0.001 , respectively). However, there was no statistically significant association between platelet count and increase in gestational age $(P=0.296)$.

Conclusion: These findings reinforce the need for supplementation and provide additional information on hematological reference values in pregnancy in Nigeria.

Keywords: anemia, thrombocytopenia, hematology, normal pregnancy, trimester

\section{Background}

Hematological profile is measured all over the world to estimate general health, because it is a reliable indicator and is a simple, fast and cost-effective test. ${ }^{1}$ In addition, the hematological profile is considered to be one of the factors affecting pregnancy and its outcome..$^{2,3}$ During pregnancy, changes occur and can be observed in hematological indices such as red blood cell (RBC) count, hemoglobin ( $\mathrm{Hb}$ ) concentration, platelet (PLT) count, and white 
blood cell (WBC) count. Some of these are decreased - for example, RBC and PLT counts - partly as a result of the physiological hemodilution that occurs in pregnancy, ${ }^{4,5}$ while others are increased, such as the WBC count. ${ }^{6}$

\section{RBC changes in pregnancy}

In pregnancy, plasma volume increases $25 \%-80 \%$ between the sixth and twenty-fourth week of gestation. ${ }^{7}$ However, the increase in RBC mass has been found to be approximately $30 \%$ between the twelfth and thirty-sixth week of gestation when iron and folate are supplemented. ${ }^{8}$ The discrepancy between the rate of increase in plasma volume and that in RBC mass leads to physiological anemia. In late pregnancy, plasma volume increases at a slower rate, inducing a slight rise in hematocrit level. These physiological changes during pregnancy make it difficult to define normal hematological reference intervals for pregnant women. ${ }^{1}$

Anemia is the most common hematological problem in pregnancy. ${ }^{9}$ In iron-affluent pregnant women, "anemia" is defined as $\mathrm{Hb}<110 \mathrm{~g} / \mathrm{L}^{10,11}$ or less than the fifth percentile of the distribution, based on age and stage of pregnancy. ${ }^{12}$ Anemia contributes to low birth weight and miscarriages and is also a primary cause of low immunity in both the mother and the child, which makes them vulnerable to several infections. ${ }^{13}$ Malaria infection causes 3\%-5\% of maternal anemia and, worldwide, about 50 million women are exposed to malaria, especially in highly endemic regions like Nigeria. ${ }^{14,15}$

\section{PLT changes in pregnancy}

The PLT count is slightly lower in pregnant than in nonpregnant women. ${ }^{16}$ Most studies report an approximate $10 \%$ lower PLT level at term compared with at pre-pregnancy. ${ }^{17,18}$ However, van Buul et $\mathrm{al}^{19}$ reported an increase in PLT count in pregnancy. The majority of pregnant women still have levels within the normal range; however, if the pre-pregnancy level is borderline or there is a more severe reduction, this may fall below the normal range. The mechanisms for this are thought to be due to dilution effects and accelerated destruction of PLTs passing over the often scarred and damaged trophoblast surface of the placenta. ${ }^{20}$ PLT counts may also be lower in women with twin compared with singleton pregnancies, possibly due to greater thrombin generation. ${ }^{21}$ Although most cases of thrombocytopenia in pregnancy are mild, with no adverse outcome for mother or baby, occasionally a low PLT count may be part of a complex disorder with significant morbidity and be (rarely) life-threatening.

Overall, about $75 \%$ of cases of PLT changes are due to gestational thrombocytopenia, $15 \%-20 \%$ secondary to hypertensive disorders, $3 \%-4 \%$ due to an immune process, and the remaining $1 \%-2 \%$ comprises rare constitutional thrombocytopenias, infections, and malignancies. ${ }^{22}$

\section{WBC changes in pregnancy}

Previous studies have reported that pregnancy is usually accompanied by leukocytosis, but the full sequential changes of the various cell types responsible for this observed leukocytosis have not been clearly determined in all geographical locations and physiological conditions. ${ }^{23-25}$ As such, the establishment of reference values of hematological indices in pregnancy is considered important.

The study reported here was designed to evaluate the values of seven major hematological parameters (packed cell volume [PCV], Hb, WBC, PLTs, mean cell volume [MCV], mean corpuscular hemoglobin [MCH], and mean corpuscular hemoglobin concentration [MCHC]) at different trimesters of pregnancy in women reporting for antenatal care at tertiary health care centers in Lagos.

\section{Subjects and methods Study population}

The study reported here was a cross-sectional study of 274 pregnant women who attended either the Lagos University Teaching Hospital or Lagos State University Teaching Hospital antenatal clinics (situated at Ifako Ijaive and Isolo General Hospitals). During the study period between February 2012 and September 2012, all pregnant women who gave informed consent and satisfied the study inclusion criterion (normotensive blood pressure $<140 / 90 \mathrm{mmHg}$ ) were recruited into the study. Pregnant women with any of the following conditions were excluded from the study: bleeding disorders, splenomegaly, connective tissue disease such as systemic lupus erythematosus, hypertension, human immunodeficiency virus (HIV), and hepatitis B infection. In addition, women on nonsteroidal anti-inflammatory drugs such as aspirin were also excluded.

Demographic data and information on drug history were collected directly from the recruited participants, and additional data - such as HIV/hepatitis B status - were extracted from clinical notes. All study participants were on routine ferrous sulfate (200 mg three times daily), folic acid (5 mg daily), and vitamin B complex (one taken three times daily) tablets.

\section{Ethics}

The research was approved by the ethics review committees of both the Lagos University Teaching Hospital and the Lagos State University Teaching Hospital. 


\section{Sample collection}

A blood sample $(4.5 \mathrm{~mL})$ was withdrawn from each participant with minimal stasis from the antecubital vein using a dry, sterile disposable syringe and needle. The blood was dispensed into tubes containing the anticoagulant ethylenediaminetetraacetic acid (EDTA). The specimens were labeled with the subject's age, and identification number. The EDTA samples were kept at room temperature until processing, which occurred within 4 hours of collection.

\section{Laboratory analysis}

Full blood count was performed using a KN-21N Hematology Analyzer (Sysmex, Kobe, Japan), a three-part auto analyzer able to test 19 parameters per sample including $\mathrm{Hb}$ concentration, $\mathrm{PCV}, \mathrm{RBC}$ concentration, $\mathrm{MCH}, \mathrm{MCV}$, MCHC, WBC count, and PLT count. Standardization, calibration of the instrument, and processing of the samples were done according to the manufacturer's instructions.

\section{Procedures}

Each blood sample was mixed well and then approximately $20 \mu \mathrm{L}$ was aspirated by allowing the analyzer's sampling probe into the blood sample and depressing the start button. Results of the analysis were displayed after about 30 seconds, after which the analyzer generated a paper copy of the results on thermal printing paper.

\section{Statistical analysis}

Data were analyzed using SPSS (v 16; IBM, Armonk, NY, USA). The descriptive data are presented herein as means \pm standard deviation (SD). Pearson's Chi-square test and one-way analysis of variance (ANOVA) were used for analytic assessment and the differences were considered statistically significant when the $P$ value obtained was $<0.05$.

\section{Results}

The mean age of the 274 pregnant women who participated in the study was $30.52 \pm 4.6$ years (range: $20-46$ years old). Most of the participants $(165 / 274 ; 60.21 \%)$ were in their second trimester at the time of the study, while $75(27.37 \%)$ were in their third trimester and $34(12.40 \%)$ were in their first trimester (Table 1). About three-quarters of the participants

Table I Participants' $(n=274)$ trimester and educational level

\begin{tabular}{|c|c|c|c|c|c|}
\hline \multicolumn{3}{|c|}{ Trimester, n (\%) } & \multicolumn{3}{|c|}{ Level of education attained, $\mathbf{n}(\%)$} \\
\hline Ist & 2nd & $3 r d$ & Primary & Secondary & Tertiary \\
\hline 34 & 165 & 75 & 7 & 63 & 204 \\
\hline$(12.40)$ & $(60.21)$ & $(27.30)$ & $(2.25)$ & $(22.99)$ & $(74.45)$ \\
\hline
\end{tabular}

(204/274; 74.45\%) had had tertiary education, 63 (22.99\%) had had secondary education, and seven (2.25\%) had had primary education (Table 1).

The overall mean hematocrit level for the study population was $30.16 \% \pm 5.55 \%$, while mean $\mathrm{Hb}$ concentration was $10.94 \pm 1.86 \mathrm{~g} / \mathrm{dL}$, mean WBC count was $7.81 \pm 2.34 \times 10^{9}$, mean PLT count was $228.29 \pm 65.6 \times 10^{9}$, $\mathrm{MCV}$ was $78.30 \pm 5.70 \mathrm{fL}, \mathrm{MCH}$ was $28.57 \pm 2.48 \mathrm{pg}$, and MCHC was $36.45 \pm 1.10 \mathrm{~g} / \mathrm{dL}$ (Table 2).

Grouped according to trimester, those in their first trimester had a mean PCV of $32.07 \% \pm 6.80 \%$, while it was $29.76 \% \pm 5.21 \%$ for those in their second trimester, and $33.04 \% \pm 3.88 \%$ for those in their third. The MCHC values were $11.59 \pm 2.35,10.81 \pm 1.72$, and $10.38 \pm 1.27 \mathrm{~g} / \mathrm{dL}$ for those in their first, second, and third trimester, respectively. Mean WBC count for the first-, second-, and thirdtrimester group was $7.31 \pm 2.38 \times 10^{9}, 7.88 \pm 2.33 \times 10^{9}$, and $8.37 \pm 2.15 \times 10^{9}$, respectively, while the mean PLT count for each group was $231.50 \pm 79.10 \times 10^{9}, 227.57 \pm 63 \times 10^{9}$, and $200.82 \pm 94.42 \times 10^{9}$, respectively. The MCV for the first-, second-, and third-trimester group was $79.7 \pm 0.966$, $78.38 \pm 5.72$, and $70.02 \pm 5.4 \mathrm{fL}$, respectively and the $\mathrm{MCH}$ for each group was $28.23 \pm 2.40,28.63 \pm 2.50$, and $28.18 \pm 1.93 \mathrm{pg}$, respectively. The MCHC for the first-, second-, and third-trimester group was $36.27 \pm 1.21$, $36.49 \pm 1.08$, and $31.34 \pm 0.75 \mathrm{~g} / \mathrm{dL}$, respectively (Table 2 ).

A statistically significant relationship was found between PCV and WBC count, and increase in gestational age ( $P=0.010$ and 0.001 , respectively). However, there was no statistically significant association between PLT count and increase in gestational age $(P=0.296)$ (Table 3$)$.

Comparing PCV with gestational age using Tamhane's $\mathrm{T} 2$ post-hoc analysis, the result of the homogeneity test of variance was significant at 0.002 , while, with ANOVA, F was found to equal 0.826 and a nonsignificant level of 0.680 was obtained. The homogeneity test of variance between WBC count and gestational age was also at a significant level of 0.048 , while, with ANOVA, F was found to equal 1.337 and a nonsignificant level of 0.161 was obtained (Table 3 ). Finally, a similar result was obtained when PLT count was compared with gestational age, with the homogeneity test of variance returning a significant value of 0.008 , while, with ANOVA, F was found to equal 1.613 and a nonsignificant value of 0.054 was obtained (Table 3 ).

\section{Discussion}

The aim of the study was to determine the overall mean values for hematological indices in pregnancy and the 
Table 2 Trimester-specific Mean Hematological Values

\begin{tabular}{|c|c|c|c|c|}
\hline \multirow[t]{2}{*}{ Parameter } & \multicolumn{4}{|l|}{ Trimester } \\
\hline & Overall & Ist & 2nd & $3 r d$ \\
\hline HCT, \% & $30.16 \pm 5.55$ & $32.07 \pm 6.80$ & $29.76 \pm 5.21$ & $33.04 \pm 3.88$ \\
\hline $\mathrm{Hb}, \mathrm{g} / \mathrm{dL}$ & $10.94 \pm 1.86$ & $11.59 \pm 2.35$ & $10.81 \pm 1.72$ & $10.38 \pm 1.27$ \\
\hline WBC count, $\times 10^{9}$ & $7.81 \pm 2.34$ & $7.37 \pm 2.38$ & $7.88 \pm 2.32$ & $8.31 \pm 2.15$ \\
\hline PLT count, $\times 10^{9}$ & $228.29 \pm 6.56$ & $231.50 \pm 79.10$ & $227.57 \pm 63.00$ & $200.82 \pm 94.4$ \\
\hline$M C V, f L$ & $78.30 \pm 5.70$ & $79.70 \pm 0.96$ & $78.38 \pm 5.72$ & $70.02 \pm 5.40$ \\
\hline $\mathrm{MCH}, \mathrm{pg}$ & $28.57 \pm 2.48$ & $28.23 \pm 2.40$ & $28.63 \pm 2.50$ & $28.18 \pm 1.92$ \\
\hline $\mathrm{MCHC}, \mathrm{g} / \mathrm{dL}$ & $36.45 \pm 1.10$ & $36.27 \pm 1.21$ & $36.49 \pm 1.08$ & $31.34 \pm 0.75$ \\
\hline
\end{tabular}

Note: Data presented are mean \pm standard deviation.

Abbreviations: $\mathrm{Hb}$, hemoglobin; $\mathrm{HCT}$, hematocrit; $\mathrm{MCH}$, mean corpuscular hemoglobin; $\mathrm{MCHC}$, mean corpuscular hemoglobin concentration; $\mathrm{MCV}$, mean cell volume; PLT, platelet; WBC, white blood cell.

trimester-specific mean values for hematological indices in pregnant women. We found a progressive decline in $\mathrm{Hb}$ concentration from the first to the third trimester, but a drop from first to the second trimester. There was a slight rise in the PCV in the third trimester. These findings corroborate those of a similar study undertaken in Ibadan, south-western Nigeria, by Akingbola et al in 2006, ${ }^{26}$ which reported exactly the same pattern. The progressive decline in $\mathrm{Hb}$ concentration from the first to third trimester may be due to an increased demand for iron as pregnancy progresses. More iron is required to meet the expansion of maternal $\mathrm{Hb}$ mass and the needs of fetal growth. The additional progesterone and estrogen that are secreted by the placenta during pregnancy cause a release of renin from the kidneys. Renin stimulates the aldosterone-renin-angiotensin mechanism, leading to sodium retention and increased plasma volume. The increase in plasma volume is relatively greater than the increase in red cell mass, which results in a fall in maternal $\mathrm{Hb}$, hence the physiological anemia that occurs in pregnancy.

Despite the physiological hemodilution associated with pregnancy, which also contributes to the drop in PCV in the first and second trimester, in late pregnancy, plasma volume increases at a slower rate, inducing a slight rise in hematocrit that may account for the slight rise in PCV in the third trimester. ${ }^{1}$

The increase observed in WBC count from the first to third trimester in this study is consistent with the findings of Akingbola et $\mathrm{al}^{26}$ and Onwukeme and Uguru. ${ }^{23}$ The increase is primarily due to an increase in neutrophils and

Table 3 Results of Statistical Analysis

\begin{tabular}{llll}
\hline Parameters & $\boldsymbol{P}$ & F & Significant value \\
\hline PCV vs gestational age & 0.010 & 0.826 & 0.680 \\
WBC count vs gestational age & $0.00 \mathrm{I}$ & $\mathrm{I} .337$ & $0.16 \mathrm{I}$ \\
PLT count vs gestational age & 0.296 & $\mathrm{I} .6 \mathrm{I} 3$ & 0.054 \\
\hline
\end{tabular}

Abbreviations: PCV, packed cell volume; PLT, platelet; WBC, white blood cell; vs, versus. may represent a response to stress due to redistribution of the WBCs between the marginal and circulating pools. Pain, nausea, vomiting, and anxiety have been reported to cause leukocytosis in the absence of infection. ${ }^{27} \mathrm{~A}$ rising WBC count in pregnancy is not a reliable indicator of infection in subclinical chorioamnionitis; rather, clinical methods of detection such as maternal pyrexia, offensive vaginal discharge, and fetal tachycardia are better indicators, especially of preterm labor and membrane rupture. ${ }^{28}$

This study also reported a gradual reduction in PLT count as pregnancy advanced, which is also consistent with Akingbola et al's study. ${ }^{26}$ Due to hemodilution secondary to expansion of plasma volume, the PLT count in normal pregnancies may decrease by approximately $10 \%$, with most of this decrease occurring during the third trimester, ${ }^{17,29,30}$ although the absolute PLT count tends to remain within the normal reference range in most patients. ${ }^{17,29-31}$

After anemia, thrombocytopenia is the second most common hematologic abnormality that occurs during pregnancy. "Thrombocytopenia" is classically defined as a PLT count of less than $150,000 \times 10^{9} / \mathrm{L} .{ }^{22,33}$ Counts from 100,000 to $150,000 \times 10^{9} / \mathrm{L}$ are considered mildly depressed; from 50,000 to $100,000 \times 10^{9} / \mathrm{L}$, moderately depressed; and of less than $50,000 \times 10^{9} / \mathrm{L}$, severely depressed. ${ }^{34}$ The overall incidence of thrombocytopenia in pregnancy is $8 \%$, but when patients with obstetric or medical conditions are excluded, the incidence drops to $5.1 \% .^{32}$

MCV declined from the first to third trimesters in this study, while $\mathrm{MCH}$ remained relatively stable through all trimesters. MCHC was stable in the first and second trimester but dropped in the third. These findings may be a reflection of iron deficiency anemia.

Finally, of note, in line with previous studies on early versus late enrollment into antenatal care, we found that a preponderance of the participants in this study registered for antenatal care in their second trimester, while only 
$12.4 \%$ of participants had registered early for antenatal care. This finding is in keeping with various studies from different regions in Nigeria that have reported that most pregnant women registered when their pregnancy was beyond 20 weeks. ${ }^{35-38}$

A limitation of this study was the lack of a control group of unsupplemented women. However, such a group may not have gained ethical approval, considering the high prevalence of anemia in our environment. Another important limitation of this study may have been the reliability of the information provided by participants and data extracted from clinical notes.

\section{Conclusion}

The findings of this study reinforce the need for supplementation and provide additional information on hematological reference values in pregnancy in Nigeria.

\section{Disclosure}

The authors declare no conflicts of interest in this work.

\section{References}

1. Shen C, Jiang YM, Shi H, et al. A prospective, sequential and longitudinal study of haematological profile during normal pregnancy in Chinese women. J Obstet Gynaecol. 2010;30(4):357-361.

2. Klebanoff MA, Shiono PH, Selby JV, Trachtenberg AI, Graubard BI. Anemia and spontaneous preterm birth. Am J Obstet Gynecol. 1991;164(1 Pt 1):59-63.

3. Allen LH. Anemia and iron deficiency: effects on pregnancy outcome. Am J Clin Nutr. 2000;7(Suppl 5):1280S-1284S.

4. Cabaniss CD, Cabaniss ML. Physiologic hematology of pregnancy. In: Kitay DZ, editor. Hematologic Problems in Pregnancy. Oradell, NJ: Medical Economics; 1987:3-14.

5. Kelton JG, Cruickshank M. Hematologic disorders of pregnancy. In: Burrow GN, Ferris TF, editors. Medical Complications During Pregnancy, 3rd ed. Philadelphia, PA: WB Saunders; 1988:65-91.

6. Pitkin RM, White DL. Platelet and leukocyte counts in pregnancy. JAMA. 1979;243(24):2696-2698.

7. Lund CJ, Donovan JC. Blood volume during pregnancy. Significance of plasma and red cell volumes. Am J Obstet Gynecol. 1967;98(3): 394-403.

8. Taylor DJ, Lind T. Red cell mass during and after normal pregnancy. Br J Obstet Gynaecol. 1979;86(5):364-370.

9. Williams MD, Wheby MS. Anemia in pregnancy. Med Clin North Am. 1992;76(3):631-647.

10. Svanberg B. Absorption of iron in pregnancy. Acta Obstet Gynecol Scand Suppl. 1975;48:1-108.

11. Foulkes J, Goldie DJ. The use of ferritin to assess the need for iron supplements in pregnancy. J Obstet Gynaecol. 1982;3(1):11-16.

12. James TR, Reid HL, Mullings MA. Are published standards for haematological indices in pregnancy applicable across populations: an evaluation in healthy pregnant Jamaican women. BMC Pregnancy Childbirth. 2008;8:8.

13. Imam TS, Yahaya A. Packed cell volume of pregnant women attending Dawakin Kudu General Hospital. Kano State, Nigeria. Int Jor P App Scs. 2008;2(2):46-50.

14. World Health Organization (WHO). Prevention and Treatment of Malaria During Pregnancy. Geneva: WHO. Available from: http://pdf. usaid.gov/pdf_does/pnada621.pdf.2004. Accessed October 21, 2012.
15. Rogerson SJ, Hviid L, Duffy PE, Leke FG, Taylor DW. Malaria in pregnancy: pathogenesis and immunity. Lancet Infect Dis. 2007; $7(2): 105-117$.

16. Abbassi-Ghanavati M, Greer LG, Cunningham FG. Pregnancy and laboratory studies: a reference table for clinicians. Obstet Gynecol. 2006;114(6):1326-1331.

17. Boehlen F, Hohlfeld P, Extermann P, Perneger TV, de Moerloose P. Platelet count at term pregnancy: a reappraisal of the threshold. Obstet Gynecol. 2000;95(1):29-33.

18. Jensen JD, Wiedmeier SE, Henry E, Silver RM, Christensen RD. Linking maternal platelet counts with neonatal platelet counts and outcomes using the data repositories of a multihospital health care system. Am J Perinatol. 2011;28(8):597-604.

19. van Buul EJ, Steegers EA, Jongsma HW, Eskes TK, Thomas CM, Hein PR. Haematological and biochemical profile of uncomplicated pregnancy in nulliparous women; a longitudinal study. Neth $J$ Med. 1995;46(2):73-85.

20. Fay RA, Hughes AO, Farron NT. Platelets in pregnancy: hyperdestruction in pregnancy. Obstet Gynecol. 1983;61(2):238-240.

21. Tsunoda T, Ohkuchi A, Izumi A, et al. Antithrombin III activity and platelet count are more likely to decrease in twin pregnancies than in singleton pregnancies. Acta Obstet Gynecol Scand. 2002; 81(9):840-845.

22. Burrows RF, Kelton JG. Thrombocytopenia at delivery: a prospective survey of 6715 deliveries. Am J Obstet Gynecol. 1990;162(3):732-734.

23. Onwukeme KE, Uguru VE. Haematological values in pregnancy in Jos. W Afr J Med. 1990;9(2):70-75.

24. Good W, Macdonald HN, Hancock KW, Wood JE. Haematological changes in pregnancy following ovulation-induction therapy. J Obstet Gynaecol Br Commonw. 1973;80(6):486-490.

25. Mitchell GW Jr, Jacobs AA, Haddad V, Paul BB, Strauss RR, Sbarra AJ. The role of the phagocyte in host-parasite interactions. XXV. Metabolic and bactericidal activities of leukocytes from pregnant women. Am J Obstet Gynecol. 1970;108(5):805-813.

26. Akingbola TS, Adewole IF, Adesina OA, et al. Haematological profile of healthy pregnant women in Ibadan, south-western Nigeria. J Obstet Gynaecol. 2006;26(8):763-769.

27. Milhorat AT, Small SM, Diethelm O. Leukocytosis during various emotional states. Arch Neurol Psych. 1942;47(5):779-792.

28. Guidelines Committee of the Royal College of Obstetricians and Gynaecologists (RCOG). Preterm Prelabour Rupture of Membranes. 2010. Green-top Guideline No 44. London: RCOG; 2006.

29. McCrae KR. Thrombocytopenia in pregnancy: differential diagnosis, pathogenesis, and management. Blood Rev. 2003;17(1):7-14.

30. Ballem PJ. Hematological problems of pregnancy. Can Fam Physician. 1988;34:2531-2537.

31. Burrows RF, Kelton GJ. Fetal thrombocytopenia and its relation to maternal thrombocytopenia. N Engl J Med. 1993;329(20):1463-1466.

32. Sullivan CA, Martin JN Jr. Management of the obstetric patient with thrombocytopenia. Clin Obstet Gynecol. 1995;38(3):521-534.

33. Shehata N, Burrows R, Kelton JG. Gestational thrombocytopenia. Clin Obstet Gynecol. 1999;42:327-334.

34. Magann EF, Martin JN Jr. Twelve steps to optimal management of HELLP syndrome. Clin Obstet Gynecol. 1999;42(3):532-550.

35. Ghororo EP, Igbafe AA. Antenatal care: some characteristics of the booking visit in a major teaching hospital in the developing world. Med Sci Monit. 2000;6(3):519-522.

36. Adeyemi AB, Makinde ON, Ajenifuja KO, et al. Determinants of antenatal booking time in a South-Western Nigeria setting. West Afr J Med. 2007;26(4):293-297.

37. Okunlola MA, Ayinde OA, Owonikoko KM, Omigbodun AO. Factors influencing gestational age at antenatal booking at the University College Hospital, Ibadan, Nigeria. J Obstet Gynecol. 2006;26(3):195-197.

38. Oladokun A, Oladokun RE, Morhanson-Bello I, Bello AF, Adedokun B. Proximate predictors of early antenatal registration among Nigerian pregnant women. Ann Afr Med. 2010;9(4):222-225. 
International Journal of Women's Health

Dovepress

\section{Publish your work in this journal}

The International Journal of Women's Health is an international, peer- a very quick and fair peer-review system, which is all easy to use. reviewed open-access journal publishing original research, reports, editorials, reviews and commentaries on all aspects of women's healthcare including gynecology, obstetrics, and breast cancer. The Visit http://www.dovepress.com/testimonials.php to read real quotes from published authors.

manuscript management system is completely online and includes

Submit your manuscript here: http://www.dovepress.com/international-journal-of-womens-health-journal 